\title{
Recent Developments in School-Based Health Services in Turkey
}

\author{
(1) Serpil Uğur Baysal, (1) Tolga İnce \\ Dokuz Eylül University Faculty of Medicine, Department of Pediatrics, Division of Social Pediatrics, İzmir, Turkey
}

\begin{abstract}
Seventeen million students aged between five and nineteen years and one million teachers and staff attending over 55.000 schools account for more than twenty percent of the Turkish population. They can present with a broad range of medical disorders. It is important that they have services designed to deal with their health problems. The aim of this article is to review the recent developments in school health services in Turkey. Recent projects aiming to improve school-based health services and health research at schools have also been reviewed. In countries where social inequalities are prevalent, school-based health services have a particular importance in reaching out to children who do not have access to appropriate health care. Nowadays, it is encouraging to observe that the topic of "school health" has gained interest among managers and health workers in Turkey.

Keywords: Health policy, school health, Turkey health project
\end{abstract}

\section{Introduction}

Turkey's population reached 78 million recently. Although the population is getting older in recent decades, the proportion of the young is still greater than those of many other countries. The child population is approximately $30 \%$, and in this population, the percentages of $0-4,5-9,10-14$ and $15-17$ years are $27.6 \%, 27.7 \%, 27.4 \%$ and $17.3 \%$ respectively (1-3). These rates do not show any significant difference by year or sex. The highest child population (47.8\%) can be found in two provinces in South-East Anatolia. The region with the lowest proportion of child population is West Marmara (21.9\%). The lowest proportion of child population is in one province in East Anatolia (18.0\%) and two provinces in the West Marmara Region (the most part in Europe) $(1,2)$. The population living in poverty is 16.706 .000 ; the ratio of children in this population is $44.3 \%$. Children living in poverty is highest in the South-East, North-East and Central Anatolia, whereas the lowest levels are in the West Marmara, Aegean and East Black Sea Regions (2). Seventeen million students aged between 5 and 19 years and one million teachers and staff in 55.000 schools corresponds to approximately $20 \%$ of Turkey's population and they are interfaced directly with schools (3). Students can present with a broad range of medical disorders. It is important that they have health care services designed to deal with their medical issues $(4,5)$. In 1936, an Organization of the Ministry of Health and Civil Law described school health services as the responsibility of the government. Since 1946, UNICEF has promoted programs at schools for nutrition and prevention of infections. The ministry of education, health issues department published a health services application guide in 1992 (5). Services were limited to vaccinations and screenings at school enrollment, and priority was given to rural areas. Today, all social security plans are united in a single "general health insurance". Family physicians and practitioners are appointed as "family 
doctors". Turkey has a relatively medium-strong structure for primary care (governance, economy and workforce). However, it has relatively low-strong primary care process dimensions (access, comprehensiveness, continuity and coordination of care). Continuity of the policies is important. Turkey is a transitional society; social, political, economic, nutritional and lifestyle changes have occurred in Turkey in recent decades. One of these changes is school health services based on the program of transformation in health (THP) (6-10). Since 2003, a comprehensive reform program in the health sector, which is called the transformation in health program, has been enacted. This program aimed at improving the efficiency and quality of the health system $(7,9,10)$. Ten years after its adoption, maternal and child mortality indicators showed significant improvements (7,913). The health issues of school age children and adolescents were not among the priorities of the health service provision before the transformation of health in Turkey. The major priorities of the Mother and Child Health Department of the Turkish Ministry of Health, for a long period of time, were focused on mother and newborn health (7-9). However, it is encouraging to observe that the topic of "school health" has gained interest among managers and health workers in Turkey recently. In 2011, a Health System Performance Assessment was carried out to measure the achievements of the THP (12). The Turkish School of Public Health was in charge of coordinating national and international public health work on behalf of the ministry of health and took the technical lead. The first strategic plan for the health sector covered the period 2010-2014 (11). It was reviewed in 2012 to ensure consistency with the national development plan, policy papers, the ministry of health's strategy and health system needs. The current second Strategic Plan covers the period 2013-2017 (13). Turkey's health system has been characterized by centralization of decision-making at both regional and local levels (14).

\section{Developments in School Health Services}

A variety of special programs by the ministry of health called "Child Health Programs" are being carried out to reduce infant and children mortality rates and foster healthier babies and children. Progress has been achieved as a result of these programs (15). The Turkish Ministry of Education Department of Health was responsible for school health, in cooperation with the related institutions. Health screening has covered 1.5 million students each year in primary schools since 1982 (6). Turkey's Ministry of Health has been responsible for school health since January 2005 in collaboration with the ministry of education. Principles related to school health in Turkey were determined by circular number 2008/58 (16). Physicians working at Regional Health Centers are mainly responsible. A team approach is essential. School health services have four aspects: student's health, health of school staff, health education and the school environment. A new comprehensive online guidance on "School Health for Primary Level Health Workers" was prepared (17). The 'Turkey Health Promotion Workshop' was held in February
2010 by the ministry of health; the 'School Health Working Group Report' was written. The 'First National School Health Symposium' took place in May 2010 (18).

\section{Projects in School Health Services}

\section{Health Promoted Schools}

The European Network of Health Promoting Schools (ENHPS) is a project by the World Health Organization (WHO), European Assembly and European Committee applied in over 40 countries in Europe. The project aims to improve the psychological and social environment in school as well as the health status of the children $(19,20)$.

The following was accomplished within the ENHPS project:

- The project was introduced in a three-day meeting to the trainers and coordinators.

- A "Project Support Centre", a technical and an advisory committee, were formed within the Ministry of Health.

- School coordinators were selected, and a health center was established in each school.

- Related published materials were prepared; workshops were organized for the teachers and trainers on several topics including psychological, physical development and demands of children.

- Summer schools were organized for students educating them on nutrition, such as; a healthy life, first-aid and public speaking.

- The project is being evaluated at six monthly intervals mainly by reports from the schools and questionnaires given to students and teachers.

This project was approved in 1995 in Turkey and initiated in collaboration with the ministry of health and ministry of education in 10 schools in seven cities encompassing 42.817 students and 1.512 teachers $(5,7)$.

\section{School-Based Health Service Project}

Based on a strategic approach, a school-based health service project aimed to become an application model to enhance quality and to promote awareness of children's health including mental health. It was initiated in order to implement widespread practical use of this health care model in Turkey $(21,22)$. An elementary school located in a semi-urban area of istanbul where the students come from immigrant families with a low socioeconomical level was selected for this project. The study showed that oral and dental health problems; acute diseases including acute respiratory infections; chronic symptoms and disorders such as enuresis, chronic recurrent pain; mental health problems which were mainly learning difficulties and behavioral problems; vision disturbances and skin disorders were found to be the main health issues $(5,21,22)$.

\section{Mental Health Project}

Approximately, 1.5 million students are screened annually for health in primary schools by Turkey's Population Health 
Council. Mental health problems were reported as less than one percent in the 1990s (6). In crowded classes, underestimation or ignorance of symptoms by teachers is common. Mental health problems constituted up to $12 \%$ of all health problems; $22 \%$ of students had learning difficulties, behavioral problems or other mental health issues in a school based health services project (21). Hence, it is necessary to develop a different and comprehensive tool to detect mental health problems. Nowadays, most schools have guidance counselors. Guidance and Research Centers should be strengthened for both organization and staff. Families must learn how they can reach and use these services. For the continuity of health care services for child development, families' support is needed for the prevention and early detection of mental health issues at schools. School teachers are expected to recognize and report students with learning and behavioral problems. Counselor teachers are responsible for taking care of the child after an interview. If needed, counselor teachers send students to Guidance and Research Centers. Students also can be referred to public or university hospitals for further evaluation and therapy $(6,21,22)$.

\section{Oral and Dental Health Projects}

The proportion of the students with caries or at high risk of caries, those who do not brush their teeth regularly or at all, is high in Turkey $(23,24)$. Relevant topics for the success of school oral health projects are: considering special needs of the child's dentition, informing and guiding families about treatments, involving the student, teacher and families when giving oral health education. Additional means to provide sustainability to the health education, such as ensuring that all children can access a toothbrush and toothpaste, recognizing children who are at high-risk and applying extra preventive measures to them, establishing regular and supervised brushing at school as a daily habit, applying fluoride, giving knowledge of nutrition and maintaining a supportive environment should be implemented (24). A few assessment criteria can be used for screening dental health such as: the number of caries in primary and permanent teeth, the grade of the caries for both primary and permanent teeth (decay number per student); malocclusion proportion. Students should also be assessed using number of fillings and extractions and also tooth-brushing habits. For students with high risk, a 1\% sodium fluoride gel should be applied on their teeth $(23,24)$.

\section{Safe Schools Programs}

Children in penal institutions have increased $(6.132$ children) in Turkey. The types of crimes are robbery, vandalism and assault, in order of prevalence. The proportion of children in penal institutions by age is as follows: 18\%, 12-14 years; $82 \%, 15-17$ years. $3.8 \%$ of all convicted are between $12-17$ years, and male ratio is $97 \%$ (2). The main issues regarding safety at schools are violence, bullying and traffic and other unintentional injuries on the way to or from schools. Schools are responsible for ensuring safety and reducing risks of injury at school. 'Safe school' is a new concept in childhood safety. Safe schools programs have been developed in Turkey since 2006. The "School safety" approach is being conducted as a subprogram under the WHO Safety Population Program. Safety programs should be integrated into school health programs (25).

\section{Nutrition Friendly Schools}

The program of Nutrition Friendly Schools has been implemented since September 2013 by the WHO in 17 countries from Europe using the criteria of nutrition friendly schools initiative (26). The program covers preschools, elementary schools, middle and high schools. It is aimed at fighting against childhood obesity and at promoting sufficient and well-balanced nutrition and acquiring the habit of regular physical activity within the context of the project. Hence, the nutrition education is given to students in schools, the physical training lessons are being carried out (at least two hours per week) and a school environment supporting

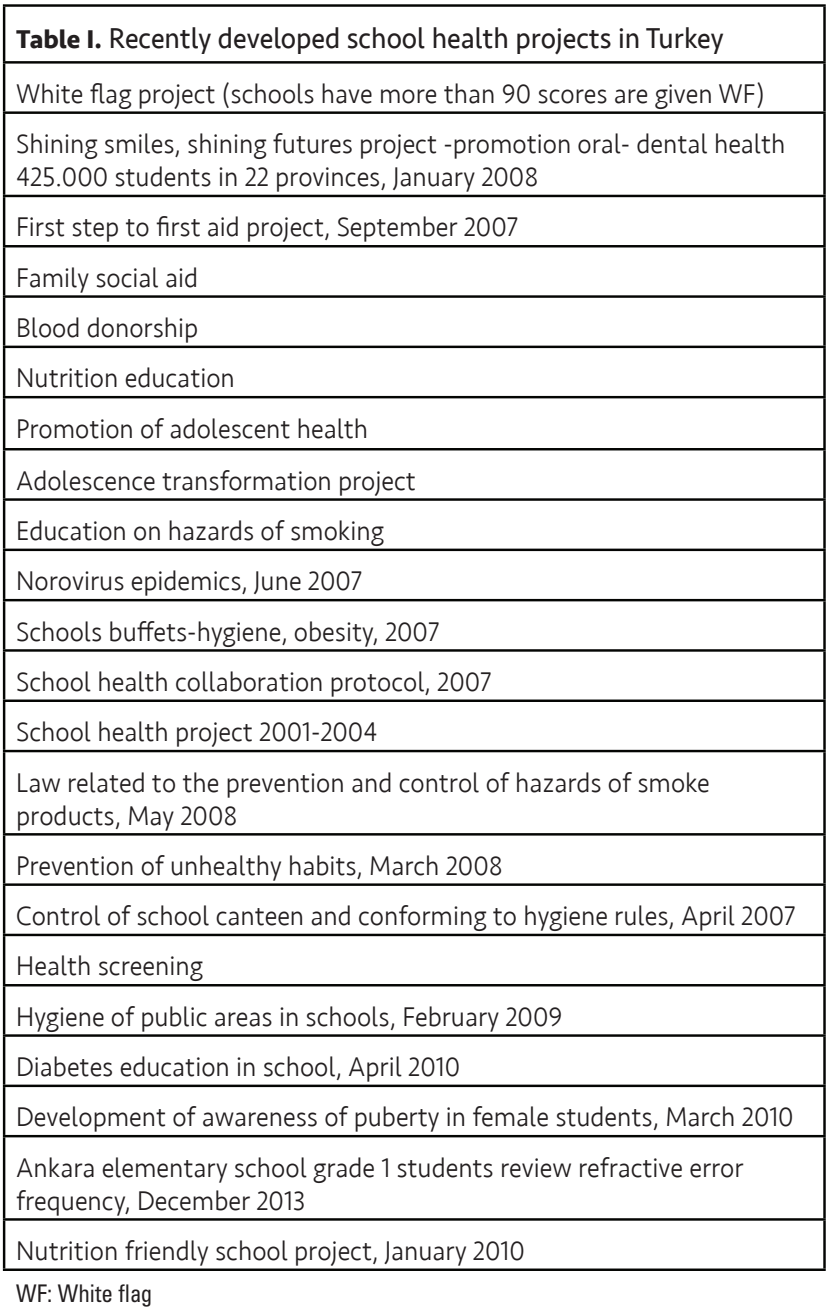


balanced nutrition is formed. 1423 schools had been certified with the "certificate of nutrition friendly school" through the Nutrition Friendly Schools Programme as of 2015 (27). Table I shows recently developed projects related to school health in Turkey $(27,28)$.

\section{Research at Schools}

\section{Overweight and Obesity}

Several studies were performed between 2000 and 2010. They revealed prevalence rates of $10.3 \%-17.6 \%$ and $1.9 \%$ $7.8 \%$ for overweight and obesity respectively, in children aged 6-16 years. Metabolic syndrome was found in $2.3 \%$ of Turkish school children aged 10-19 years. This rate was $28.0 \%$ in obese children. Public measures have been initiated by the state to control the rising prevalence of obesity (29). Neyzi et al. (30) showed that weight-for-age values indicate an increase in obesity among Turkish children aged 6 to 18 years. Height values for both sexes in all age groups were close to the updated 2000 USA growth references and showed an increase from the data on Turkish children born 30 years earlier. Weight values were high compared to reference data on US children and the previous data on Turkish children.

\section{Health Behaviors}

A descriptive study showed that the most common risky health behaviors in adolescents include substance abuse, risky sexual behaviors, violence and accidents. The age of the participants $(n=230)$ was $16.1 \pm 1.17$ years, and gender was proportioned equally. The risky health behaviors were shown to be alcohol consumption at $10.4 \%$, smoking at $1.7 \%$, paint thinner inhalation at $1.3 \%$, and drug abuse at $0.9 \%$. However, these rates were lower when compared to the literature. Health promotion activities are needed (31). The results of another cross-sectional study on selfreported health behaviors among high school students were: $33.8 \%$ had experimented with smoking, $26.3 \%$ smoked one cigarette during the 30 days before the survey, $14.9 \%$ smoked cigarettes regularly during the 30 days before the survey, $54.1 \%$ had experimented with drinking alcohol, 38.4\% drank alcohol during the 30 days before the survey, $31.6 \%$ got drunk, $10.9 \%$ were adequately physically active, $59.9 \%$ watched TV for long periods of time, $72.8 \%$ used the internet for long periods of time, $48.1 \%$ had breakfast regularly, $36.2 \%$ ate an adequate amount of fruit, $14.1 \%$ ate an adequate amount of vegetables, $31.3 \%$ ate candies and chocolate very often, $18 \%$ drank soft drinks very often, $30.3 \%$ were bullied, $29.9 \%$ bullied others and $41 \%$ were involved in a physical fight (32). Adolescent friendly health services are needed; physicians should evaluate each adolescent for health behaviors during each visit; prevention programs with a health promotion perspective are necessary.

\section{Negative Childhood Experiences}

Despite much effort and progress in studies on child abuse and neglect in Turkey recently, the number of abused children is increasing; many problems pertaining to the care and protection of these children could not be solved yet. The newly formed ministry of family and social politics, and the Centers of Child Surveillance belonging to the ministry of health are quite new institutions working in this area. Sofuoğlu et al. (33) participated in the Child Abuse and Neglect Balkan Epidemiologic Study-European Union Project aimed at determining the frequencies of negative childhood experiences in past year and negative childhood experiences throughout life in 11, 13 and 16 year-age group children. The frequencies of negative childhood experiences for the last one year and for the life-long period were determined using the International Society for the Prevention Child Abuse screening tool in Turkey for the first time in three provinces for 7.500 children. The frequency of psychological and physical negative childhood experiences and neglect throughout life was found to be $70.5 \%, 58.3 \%$ and $42.6 \%$ in the 11, 13 and 16-year age groups respectively; the frequencies in the last one year were found to be $62.7 \%, 46.0 \%$ and $37.5 \%$ respectively. The frequency of negative childhood experiences related with child abuse and neglect screened were found to be $42 \%-70 \%$ and it was extrapolated that we are confronted with a very significant public health problem and adult health risk in these regions of Turkey.

\section{Conclusion}

Turkey is a transitional society; social, political, economic, nutritional and lifestyle changes have occurred in Turkey in recent decades. One of these changes is school health services based on the THP. The projects and studies aiming to improve the school-based health services have been implemented. Approximately twenty percent of the Turkish population can be seen in a school setting. School health services can be used as an effective way to integrate psychosocial care, medical care and health promotion. It is important to develop strategies and standards for school-based health centers to deal with mental and physical health problems. Health screening should also include a psychosocial risk assessment. Poverty, low education levels, lack of social security of parents and immigration are the main points that influence the effectiveness of school-based health services. The collaboration with, involvement of and contribution by teachers, parents, social workers and volunteers, as well as health workers trained in school health are needed for the efficacy of these programs (20).

In countries where social inequalities are prevalent, school-based health services have a particular importance in reaching out to children who do not have access to appropriate health care. Nowadays, it is encouraging to 
observe that the topic of 'school health' has gained interest among managers and health workers in Turkey.

\section{Acknowledgement}

We thank pediatrician Selda Sivaslıoğlu, MD for her valuable contribution in the literature review.

\section{Ethics}

Peer-review: External and internal peer-reviewed.

\section{Authorship Contributions}

Concept: S.U.B., T.I., Design: S.U.B., T.I., Literature Search: S.U.B., T.I., Writing: S.U.B., T.i.

Conflict of Interest: No conflict of interest was declared by the authors.

Financial Disclosure: The authors declared that this study received no financial support.

\section{References}

1. Hacettepe University Institute of Population Studies. 2013 Turkey Demographic and Health Survey. Hacettepe University Institute of Population Studies, T.R. Ministry of Development and TÜBITAK, Ankara, Turkey, 2014.

2. Turkey Statistical Institute, the National Education Statistics 2014-2015. http://www.turkstat.gov.tr/PreTablo.do?alt id=1018 (Date of access: 05.02.2017)

3. Ellen Rimsza M, Kirk GM. Common Medical Problems of the College Student. Pediatr Clin Nort Am 2005;52:9-24.

4. Uğur Baysal S, Çağlayaner H. Approach to common health issues at school age. Klinik Çocuk Forumu Dergisi 2005;3:26-44.

5. The Turkish Republic, The Ministry of National Education, Health Issues Department, Health Services Application Guide. Ankara: National Education Printing House; 1992.

6. The Turkish Ministry of Health. http://www.saglik.gov.tr/TR/ ana-sayfa/1-0/20110521.html. (Date of access: 15.02.2017)

7. Kringos DS, Boerma WGW, Bourgueil $Y$, et al. The strength of primary care in Europe: an international comparative study. $\mathrm{Br}$. Gen Pract 2013;63:742-50.

8. Transformation in Health Project. https://www.turkiye.gov.tr. (Date of access: 05.02.2017)

9. Akdağ R. Health Transformation Program in Turkey. Progress Report. Republic of Turkey, Ministry of Health Publication No: 807, Ankara, Turkey, 2009.

10. Strategic Plan 2010-2014. Ankara: Ministry of Health of Turkey; 2010 http://ekutuphane.sagem.gov.tr/kitap. php?id=240\&k=strategic_plan_2010_2014. (Date of access: 05.02.2017)

11. Turkey health system performance assessment 2011 Copenhagen: WHO Regional Office for Europe; 2012: 95. http:// www.euro.who.int/en/countries/turkey/publications/ turkeyhealth-system-performance-assessment-2011. (Date of access: 11.02.2017)

12. Strategic Plan 2013-2017. Ankara: Ministry of Health of Turkey; 2012. http://sbu.saglik.gov.tr/Ekutuphane/kitaplar/ stratejikplaning.pdf. (Date of access: 10.03.2017)

13. Strategic planning for health: a case study from Turkey. Copenhagen: WHO Regional Office for Europe; 2015. http:// www.euro.who.int/en/countries/turkey/publications/ strategic-planning-for-health-a-case-study-from-turkey. (Date of access: 10.03.2017)
14. Özbaş S, Tezel B, Aydın \$, Bolat H, Köse MR. The situation of children's health in Turkey. Çocuk Sağığı ve Hastalıkları Dergisi 2012:55:71-6.

15. Turkish Republic Basic Health Services General Directorate, Circular for School Health Services. September 2008.

16. School Health Guide for primary level health workers. http:// sbu.saglik.gov.tr/Ekutuphane/kitaplar/okulsagligi.pdf. (Date of access: 20.02.2017)

17. School Health Symposium. http://www.okulsagligi.org/ anasayfa. (Date of access: 07.03.2017)

18. Stewart-Brown S. What is the evidence on school health promotion in improving health or preventing disease and, specifically, what is the effectiveness of the health promoting schools approach? Copenhagen, WHO Regional Office for Europe (Health Evidence Network report. http://www.euro. who.int/document/e88185.pdf. (Date of access: 27.01.2017)

19. Burgher MS, Rasmussen VB, Rivett D. The European Network of Health Promoting Schools.http://www.schoolsforhealth.eu/ upload/TheENHPStheallianceofeducationandhealth.pdf. (Date of access: 27.01.2017)

20. Baysal SU, Özmen B, Parman T, Sahip Y, Bulut A, Gökçay G. A mental health screening project in Istanbul, Turkey. I Sch Health 2004; 74:341-3.

21. Child Health Foundation. İstanbul University, Institute of Child Health. Instructions of regulations to develop school health services in Turkey (Proof). İstanbul, October 2004.

22. Oktay I, Bermek G, Peker K. School Oral Dental Health Problems. Klinik Çocuk Forumu 2005;3:13-6.

23. Aktı A. Oral and dental health in school health services, experiences and recommendations. Klinik Çocuk Forumu 2005;3:17-25.

24. Erol F. Okulda Güvenlik Sorununa Yol Açan Etkenlerin Belirlenmesi. Milli Eğitim Bakanlığı Eğitimi Araştırma ve Geliştirme Dairesi Başkanlığı. Ankara, 2009. http://www.meb. gov.tr/earged/earged/Okul_guvenligi.pdf. (Date of access: 27.01.2017)

25. Nutrition-friendly schools' initiative (NFSI). World Health Organization. http://www.who.int/nutrition/topics/nutrition friendly_schools initiative. (Date of access: 24.03.2017)

26. Ministry of National Education Health Issues Department. http://sdb.meb.gov.tr/projelerimiz.html. (Date of access: 27.01.2017)

27. Ministry of National Education Primary Education General Directorate. Our Projects. http://tegm.meb.gov.tr. (Date of access: 27.01.2017)

28. http://beslenme.gov.tr/content/files/okul_sutu/ek_5_bdo_ uygulama kilavuzu.pdf.

29. Bereket A, Atay Z. Current Status of Childhood Obesity and its Associated Morbidities in Turkey. I Clin Res Pediatr Endocrinol 2012;4:1-7.

30. Neyzi O, Furman A, Bundak R, Gunoz H, Darendeliler F, Bas F. Growth references for Turkish children aged 6 to 18 years. Acta Paediatrica 2006;95:1635-41.

31. Canbulat N, Yıldız S. Risky health behaviours of adolescents in Şişli District of İstanbul. Hemşirelikte Eğitim ve Araştırma Dergisi 2011;8:46-52.

32. Çavdar S, Sümer EÇ, Eliaçık K, et al. Health behaviours in high school students in İzmir, Turkey. Turk Pediatri Ars 2016;51:22-34.

33. Sofuoğlu Z, Oral R, Aydın F, et al. Epidemiological study of negative childhood experiences in three provinces of Turkey. Turk Ped Ars 2014;49:47-56. 